\title{
Preface
}

\section{Anesthetics and Alzheimer's Disease: Background and Research}

\author{
Vincenzo Fodale ${ }^{\mathrm{a}, *}$, Karen Ritchie $^{\mathrm{b}}$, Lars S. Rasmussen ${ }^{\mathrm{c}}$ and Pravat K. Mandal ${ }^{\mathrm{d}, *}$ \\ ${ }^{a}$ Department of Neurosciences, Psychiatric and Anesthesiological Sciences, University of Messina, Policlinico \\ G.Martino, Messina, Italy \\ b Institut National de la Santé et de la Recherche MédicaleU.888, Pathologies of the Nervous System: \\ Epidemiological and Clinical Research, Hôpital La Colombière, Montpellier, France \\ ${ }^{\mathrm{c}}$ Department of Anaesthesia, Copenhagen University Hospital, Copenhagen, Denmark \\ ${ }^{\mathrm{d}}$ Neurospectroscopy and Neuroimaging Laboratory, National Brain Research Center, Manesar, Gurgaon, India
}

Numerous anecdotal reports suggest that elderly subjects undergoing surgical procedures may experience long-term cognitive impairment with clinical features similar to those in patients with dementia, raising concerns that surgery and anesthesia could increase the risk of Alzheimer's disease (AD) or accelerate the progression of the condition [1]. The population of surgical patients is aging and we are thus presently confronted by both increases in the number of persons at risk of developing AD and the number of elderly persons undergoing surgical procedures. Any possible association between the two therefore merits careful consideration.

Central nervous system complications have long been associated with cardiac surgery, where significant cognitive deficits have been observed in a high proportion of patients across a wide range of intellectual abilities weeks to months after the procedure. While the area of cardiac surgery has provided the first assessments of cognitive functioning, it has been difficult to attribute observed changes specifically to anesthesia given the number of likely confounding factors, notably extracorporeal circulation, vascular disease, pain, and stress. Moreover, while preventive pharmacological interventions aiming at cerebral protection have been

\footnotetext{
* Correspondence to: Dr. Pravat K. Mandal, National Brain Research Centre, India. E-mail: pravat.mandal@gmail.com and Dr. Vincenzo Fodale, University of Messina, Italy. E-mail: vfodale@ unime.it.
}

repeatedly attempted in relation to cardiac surgery, it has been difficult to decrease the incidence of cognitive decline [2].

New interest in this area has been generated following observations of cognitive decline after non-cardiac surgery, in which the potential role of anesthetics has been highlighted [3,4].

In the last few decades, anesthesia management has clearly shown major advances in technology and drug development, permitting improvement of surgical techniques and the possibility of performing complex, prolonged surgical operations even in the very elderly and the critically ill. As a consequence, the evolution of anesthesia procedures has been considered to be amongst the greatest achievements in medicine.

In the absence of either a single coherent etiological model to explain the cause of AD or an effective treatment, recent research has focused on reduction of disease incidence through identification of risk factors. In this context the question of the association between $\mathrm{AD}$ and anesthesia has again been raised [5,6]. Accumulating clinical and epidemiological evidence has pointed to the potential adverse consequences of general anesthesia and a possible link with anesthesiainduced changes in molecules known to be involved in the pathogenesis of $\mathrm{AD}[7]$.

With regard to epidemiological evidence, the EURODEM Risk Factors Research Group performed a reanalysis of eight case-control studies exploring several 
medical conditions that had previously been suggested as possible risk factors for AD. Among these, general anesthesia was not associated with $\mathrm{AD}$ [8], however, there was considerable variation in data collection methodology and type and duration of anesthesia was not taken into account.

Two years later, the California Alzheimer Disease Diagnostic and Treatment Center Program collected data on a large database of subjects with dementia (502 subjects with vascular dementia and 810 subjects with probable AD) examining differences in risk factors. They discovered that vascular dementia subjects were more likely to have a history of general anesthesia and concluded that general anesthesia is a risk factor for vascular dementia [9]. In 1994, the Bohnen group evaluated prior exposure to general anesthesia as a potential risk factor for AD. No significant difference in mean cumulative exposure (in minutes) to general anesthesia or exposure to six or more episodes of general anesthesia were significantly associated with AD [10]. Similar negative findings have been reported by other groups using neuropsychological testing within both cross-sectional and longitudinal study designs, however, this research has been limited by low statistical power, variability in the quality of cognitive testing, and inadequate data relating to type of surgery, the time interval between surgery and follow-up, and age at exposure to anesthesia [11-13].

Additionally, epidemiological studies have not till date been able to adequately separate out the effects of anesthetics from underlying disease and associated activation of inflammation and other responses [14, 15]. Several research groups are now investigating the neurotoxic effect of anesthetic drugs and combinations of drugs. Experimental findings suggest that certain anesthetic molecules can, in laboratory models, induce changes in protein expression in the brain of animals $[16,17]$. This research has led to many important findings notably that smaller sized, inhaled anesthetics oligomerize $\mathrm{A} \beta$ peptide [18-21] and increase other proteins which have been shown to play a role in $\mathrm{AD}[22,23]$. AD is a devastating disease. After cancer, Americans fear AD most, but among adults aged 55 and older, the fear of getting $\mathrm{AD}$ is greater than the fear of cancer [24]. It is important, however, that such fears do not lead to an irrational rejection of surgery in later life. Surgery and anesthesia have done much to improve both the length and quality of life, so that the question of the relationship of dementia to anesthesia requires careful consideration and future recommendations backed by evidence-based argument. The current supplemental issue of the Journal of Alzheimer's Disease thus hopes to contribute to this ongoing constructive debate.

\section{REFERENCES}

[1] Seymour DG, Severn AM (2009) Cognitive dysfunction after surgery and anaesthesia: what can we tell the grandparents? Age Ageing 38, 147-150.

[2] Hogue CW, Jr., Palin CA, Arrowsmith JE (2006) Cardiopulmonary bypass management and neurologic outcomes: an evidence-based appraisal of current practices. Anesth Analg 103, 21-37.

[3] Moller JT, Cluitmans P, Rasmussen LS, Houx P, Rasmussen H, Canet J, Rabbitt P, Jolles J, Larsen K, Hanning CD, Langeron O, Johnson T, Lauven PM, Kristensen PA, Biedler A, van Beem H, Fraidakis O, Silverstein JH, Beneken JE, Gravenstein JS (1998) Long-term postoperative cognitive dysfunction in the elderly ISPOCD1 study. Lancet 351, 857-861.

[4] Rasmussen LS (2006) Postoperative cognitive dysfunction: incidence and prevention. Best Pract Res Clin Anaesthesiol 20, 315-330.

[5] Kuehn BM (2007) Anesthesia-Alzheimer disease link probed. JAMA 297, 1760 .

[6] Baranov D, Bickler PE, Crosby GJ, Culley DJ, Eckenhoff MF, Eckenhoff RG, Hogan KJ, Jevtovic-Todorovic V, Palotas A, Perouansky M, Planel E, Silverstein JH, Wei H, Whittington RA, Xie Z, Zuo Z (2009) Consensus statement: First International Workshop on Anesthetics and Alzheimer's disease. Anesth Analg 108, 1627-1630.

[7] Ritchie K, Carriere I, Ritchie CW, Berr C, Artero S, Ancelin ML (2010) Designing prevention programmes to reduce incidence of dementia: prospective cohort study of modifiable risk factors. BMJ (Clinical research ed) 341, c3885.

[8] Breteler MM, van Duijn CM, Chandra V, Fratiglioni L, Graves AB, Heyman A, Jorm AF, Kokmen E, Kondo K, Mortimer JA, et al. (1991) Medical history and the risk of Alzheimer's disease: a collaborative re-analysis of case-control studies. EURODEM Risk Factors Research Group. Int J Epidemiol 20(Suppl 2), S36-42.

[9] Cooper JK, Mungas D (1993) Risk factor and behavioral differences between vascular and Alzheimer's dementias: the pathway to end-stage disease. J Geriatr Psychiatry Neurol 6, 29-33.

[10] Bohnen N, Warner MA, Kokmen E, Kurland LT (1994) Early and midlife exposure to anesthesia and age of onset of Alzheimer's disease. Int J Neurosci 77, 181-185.

[11] Dijkstra JB, Van Boxtel MP, Houx PJ, Jolles J (1998) An operation under general anesthesia as a risk factor for agerelated cognitive decline: results from a large cross-sectional population study. J Am Geriatr Soc 46, 1258-1265.

[12] Gasparini M, Vanacore N, Schiaffini C, Brusa L, Panella M, Talarico G, Bruno G, Meco G, Lenzi GL (2002) A case-control study on Alzheimer's disease and exposure to anesthesia. Neurol Sci 23, 11-14.

[13] Avidan MS, Searleman AC, Storandt M, Barnett K, Vannucci A, Saager L, Xiong C, Grant EA, Kaiser D, Morris JC, Evers AS (2009) Long-term cognitive decline in older subjects was not attributable to noncardiac surgery or major illness. Anesthesiology 111, 964-970. 
[14] Krenk L, Rasmussen LS, Kehlet H (2010) New insights into the pathophysiology of postoperative cognitive dysfunction. Acta Anaesthesiol Scand 54, 951-956.

[15] Steinmetz J, Christensen KB, Lund T, Lohse N, Rasmussen LS (2009) Long-term consequences of postoperative cognitive dysfunction. Anesthesiology 110, 548-555.

[16] Kalenka A, Gross B, Maurer MH, Thierse HJ, Feldmann RE, Jr. (2010) Isoflurane anesthesia elicits protein pattern changes in rat hippocampus. $J$ Neurosurg Anesthesiol 22, 144-154.

[17] Futterer CD, Maurer MH, Schmitt A, Feldmann RE, Jr., Kuschinsky W, Waschke KF (2004) Alterations in rat brain proteins after desflurane anesthesia. Anesthesiology 100, 302308 .

[18] Mandal PK, Simplaceanu V, Fodale V (2010) Intravenous anesthetic diazepam does not induce amyloid beta-peptide oligomerization but diazepam co-administered with halothane oligomerizes amyloid beta-peptide: an NMR study. $J$ Alzheimers Dis 20, 127-134.

[19] Mandal PK, Bhavesh NS, Chauhan VS, Fodale V (2010) NMR investigations of $\mathrm{A} \beta$ peptide interactions with propofol at clinically relevant concentrations with and without aqueous halothane solution. J Alzheimers Dis 21, 1303-1309.
[20] Mandal PK, Fodale V (2009) Isoflurane and desflurane at clinically relevant concentrations induce amyloid beta-peptide oligomerization: an NMR study. Biochem Biophys Res Commun 379, 716-720.

[21] Mandal PK, Pettegrew JW (2008) Abeta peptide interactions with isoflurane, propofol, thiopental and combined thiopental with halothane: A NMR study. Biochim Biophys Acta 1778, 2633-2639.

[22] Dong Y, Zhang G, Zhang B, Moir RD, Xia W, Marcantonio ER, Culley DJ, Crosby G, Tanzi RE, Xie Z (2009) The common inhalational anesthetic sevoflurane induces apoptosis and increases beta-amyloid protein levels. Arch Neurol 66, 620-631.

[23] Xie Z, Culley DJ, Dong Y, Zhang G, Zhang B, Moir RD, Frosch MP, Crosby G, Tanzi RE (2008) The common inhalation anesthetic isoflurane induces caspase activation and increases amyloid beta-protein level in vivo. Ann Neurol 64, 618-627.

[24] MetLife Foundation's for Alzheimer's Survey What America Thinks, http://www.caregivershome.com/news/article. cfm?UID=1033, Last updated August 08, 2006, Accessed on September 15, 2010). pp. 144-154. 